\title{
PENGARUH REMUNERASI, KEPUASAN KERJA DAN KEPEMIMPINAN \\ TRANSFORMASIONAL TERHADAP KINERJA PEGAWAI DENGAN ORGANIZATIONAL CITIZEN BEHAVIOR SEBAGAI VARIABEL INTERVENING PADA SEKSI BPKB DITLANTAS POLDA JATENG
}

\author{
J. Reza Ferdiyono; Djoko Santoso \\ juve.theodore88@gmail.com. ; djoko_hw@usm.ac.id
}

Magister Manajemen, Universitas Semarang, Semarang, Indonesia

\begin{abstract}
Abstrak
Penelitian ini bertujuan untuk mengetahui pengaruh remunerasi, kepuasan kerja dan kepemimpinan transformasional terhadap kinerja anggota BPKB Ditlantas Polda Jateng melalui organizational citizen behavior sebagai variabel intervening.

Responden yang digunakan adalah 50 anggota bagian BPKB Ditlantas Polda Jateng. Data penelitian dikumpulkan dengan menggunakan kuesioner. Analisis data dilakukan dengan menggunakan Teknik Analisis Regresi Berganda, uji-t, analisis jalur, dan sobel-test.

Berdasarkan hasil penelitian diketahui bahwa (1) terdapat pengaruh positif remunerasi terhadap $O C B(2)$ Terdapat pengaruh positif kepuasan kerja terhadap $O C B$ (3) Terdapat pengaruh positif kepemimpinan transformasional terhadap $O C B$ (4) Terdapat pengaruh positif remunerasi terhadap kinerja anggota BPKB Polda Jateng. (5) Terdapat pengaruh positif kepuasan kerja terhadap kinerja anggota BPKB Polda Jateng(6) Terdapat pengaruh positif kepemimpinan transformasional terhadap kinerja anggota BPKB Polda Jateng (7) Terdapat pengaruh positif $O C B$ terhadap kinerja anggota BPKB Polda Jateng.
\end{abstract}

citizen behavior;

performance

\section{THE EFFECT OF REMUNERATION, JOB SATISFACTION, AND TRANSFORMATIONAL LEADERSHIP ON PERFORMANCE WITH ORGANIZATIONAL CITIZEN BEHAVIOR AS INTERVENING VARIABLES IN BPKB SECTION OF DITLANTAS OF CENTRAL JAVA REGIONAL POLICE}

\begin{abstract}
This study aims to determine the effect of remuneration, job satisfaction and transformational leadership on the performance of members of BPKB Ditlantas of Central Java Regional Police through organizationa citizen behavior $l$ as an intervening variable.

The respondents used were 50 members of the BPKB Directorate of Central Java Regional Police. Research data was collected using a questionnaire. Data analysis was performed using Multiple Regression Analysis Techniques, t-test, path analysis, and sobel-test.

Based on the results of the study it is known that (1) there is a positive influence on remuneration on $O C B$ (2) There is a positive influence on job satisfaction on $O C B$ (3) There is a positive influence of transformational leadership on OCB (4) There is a positive influence of remuneration on the performance (5) There is a positive influence on job satisfaction on the performance ( $t$ count $=2.236$, probability $(\rho)=0.030$ ). (6) There is a positive influence of transformational leadership on the performance (7) There is a positive influence of $O C B$ on the performance of Central Java Police BPKB members .
\end{abstract}

\footnotetext{
${ }^{\otimes}$ Alamat korespondensi : Jl Soekarno-Hatta, Semarang

E-mail: juve.theodore88@gmail.com. 


\section{PENDAHULUAN}

Sebagai etalase Polri, fungsi Lalu Lintas memiliki peran yang sangat penting bagi terbentuknya kepercayaan masyarakat terhadap Polri. Hal ini tidak terlepas dari karakteristik tugas dari Satuan Lalu Lintas yang lebih banyak memberikan pelayanan kepada masyarakat, sehingga anggota Satuan Lalu Lintas lebih sering bersentuhan langsung dengan masyarakat termasuk dalam pelayanan BPKB yang dihadapkan dengan berbagai tantangan dikarenakan semakin meningkatnya daya beli masyarakat terhadap kendaraan.

Sebagai akibat yang ditimbulkan dari bertambahnya jumlah kendaraan yang pesat tentunya akan berdampak pada bidang Lalu Lintas Angkutan Jalan. Tugas Polri di bidang LLAJ biasa disebut dengan $3 \mathrm{e}+1 \mathrm{i}$, yang terdiri dari Edukasi, Enginering, Enforcement dan Registrasi/Identifikasi, serta ditambah dengan melakukan Manajemen Operasional Lalu Lintas. Bila dijabarkan secara lebih rinci, maka dapat disimpulkan yang menjadi tugas pokok dari fungsi Lalu Lintas menurut Undang-Undang Republik Indonesia Nomor 22 Tahun 2009 tentang Lalu Lintas dan Angkutan Jalan, adalah pengujian dan penerbitan Surat Izin Mengemudi Kendaraan Bermotor; pelaksanaan registrasi dan identifikasi Kendaraan Bermotor; pengumpulan, pemantauan, pengolahan, dan penyajian data Lalu Lintas dan Angkutan Jalan; pengelolaan pusat pengendalian Sistem Informasi dan Komunikasi Lalu Lintas dan Angkutan Jalan; pengaturan, penjagaan, pengawalan, dan patroli Lalu Lintas; penegakan hukum yang meliputi penindakan pelanggaran dan penanganan Kecelakaan Lalu Lintas; pendidikan berlalu lintas; pelaksanaan Manajemen dan Rekayasa Lalu Lintas; dan pelaksanaan manajemen operasional Lalu Lintas.

Penyelenggaraan regident lantas merupakan salah satu tugas pokok dan fungsi Polri dalam urusan pemerintah di bidang registrasi dan identifikasi kendaraan bermotor dan pengemudi (Pasal 7 ayat (2) huruf e Undang-Undang Republik Indonesia Nomor 22 Tahun 2009 tentang Lalu Lintas dan Angkutan Jalan).Secara lebih khusus dijelaskan, bahwa Regident Lantas merupakan salah satu fungsi Polisi dalam menangani lalu lintas, baik untuk manusia (pengemudi) maupun kendaraan bermotor (ranmor). Regident pengemudi diwujudkan dalam pengujian dan penerbitan Surat Izin Mengemudi (SIM). Sedangkan regident ranmor diwujudkan dalam pelayanan penerbitan BPKB, STNK dan TNKB serta melakukan cek fisik dan registrasi kendaraan bermotor.

Terkait dengan BPKB yaitu Buku Pemilik Kendaraan Bermotor adalah merupakan dokumen pemberi legitimasi kepemilikan Kendaraan Bermotor yang diterbitkan Polri dan berisi Identitas Kendaraan Bermotor dan pemilik, yang berlaku selama Kendaraan Bermotor tidak dipindahtangankan. Bertolak dari Semakin meningkatnya jumlah kendaraan bermotor di wilayah hukum Ditlantas Polda Jateng berimplikasi terhadap pelayanan Ditlantas Polda Jateng dalam hal penerbitan BPKB.

Hal ini terlihat dimana Ditlantas Polda Jateng menerima permohonan warga untuk membuat BPKB yang meningkat tiap bulannya. Akan tetapi, fakta yang hingga saat ini masih terjadi dalam pelaksanaan pelayanan BPKB pada Ditlantas Polda Jateng adalah masih belum terpenuhinya standar kinerja yang terlihat dari beberapa permasalahan yang diakibatkan karena pada wilayah hukum Ditlantas Polda Jateng, jumlah kendaraan bermotor meningkat setiap tahun yang disebabkan meningkatnya daya beli masyarakat terhadap kendaraan bermotor. Data terkait perbandingan permohonan dan registrasi BPKB baru yang telah dilakukan oleh Ditlantas Polda Jateng dapat dilihat pada gambar 1 di bawah ini. 


\title{
Gambar 1 \\ Perbandingan Permohonan dan Registrasi BPKB Baru oleh Polda Jateng Tahun 2017
}

\author{
Mobil Penumpang $\square$ Mobil Bus \\ Mobil Barang
}

- Sepeda Motor $\quad$ Kendaraan Khusus

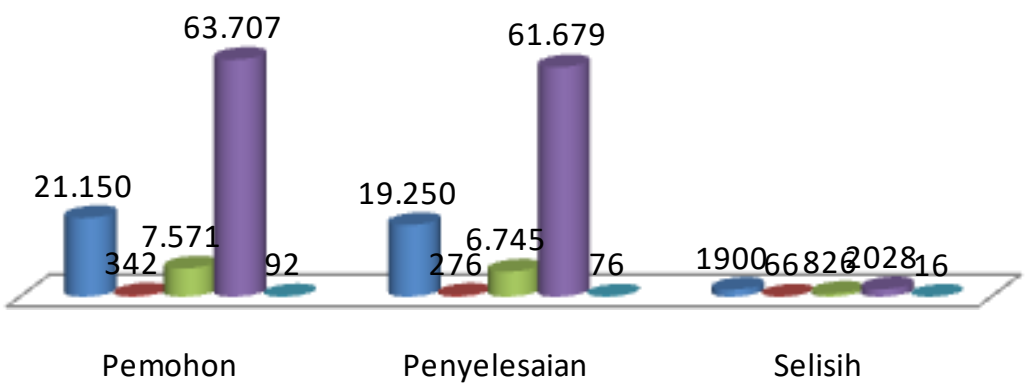

Sumber: Ditlantas Polda Jateng, 2018

Berdasarkan gambar di atas dapat diketahui semakin meningkatnya jumlah kendaraan yang telah diregistrasi oleh Ditlantas Polda Jateng dari kurun waktu tahun 2017. Peningkatan jumlah kendaraan yang teregistrasi tersebut berdampak pada semakin meningkatnya tanggung jawab dari personil bagian BPKB Ditlantas Polda Jateng. Peningkatan jumlah kendaraan yang harus diregistrasi oleh bagian BPKB Ditlantas Polda Jateng tersebut berdampak pada kurang optimalnya kinerja yang ditunjukkan oleh bagian BPKB Polda Jateng. Hal tersebut dapat diketahui dari adanya kritik yang disampaikan oleh pemohon BPKB yang mengeluhkan lambannya penerbitan BPKB. Masyarakat juga mengeluhkan mengenai kurangnya informais mengenai penerbitan BPKB, sehingga ketidaktahuan masyarakat kapan dikeluarkannya BPKB dan terkadang tidak sesuai dengan waktu yang dijanjikan, menyebabkan masyarakat harus selalu datang ke kantor pelayanan BPKB untuk menanyakan apakah BPKB kendaraan bermotornya telah jadi, sehingga tidak efisien.

Dalam menghadapi era keterbukaan seperti sekarang yang penuh dengan tantangan, Polri terdorong untuk berupaya menjadi institusi pemerintahan yang terbaik dan terdepan. Anggota Polri dituntut harus mampu bersaing dengan terus meningkatkan produktivitas, efisiensi, efektifitasnya. Lembaga Polri dalam kegiatannya menginginkan agar para anggota meningkatkan kinerjanya. Hal ini sejalan dengan misi ketiga dari Kapolri, yaitu mewujudkan pemberdayaan kualitas sumber daya manusia Polri yang profesional dan kompeten, yang menjunjung etika dan HAM. Misi tersebut dapat tercapai apabila anggota Polri, dalam hal ini adalah anggota Ditlantas Polda Jateng dapat menunjukkan kinerja yang maksimal.

Instansi Kepolisian perlu melakukan pembenahan secara kualitas dari SDM, sehingga kinerja yang ditunjukkan dapat semakin maksimal. Torang (2013) menyatakan bahwa kinerja (performance) adalah kuantitas dan atau kualitas hasil kerja individu atau sekelompok di dalam organisasi dalam melaksanakan tugas pokok dan fungsi yang berpedoman pada norma, standar operasional prosedur, kriteria dan ukuran yang telah ditetapkan atau yang berlaku dalam organisasi. Setiap anggota organisasi dituntut untuk dapat menunjukkan kinerja yang maksimal guna mencapai tujuan yang telah ditetapkan 
oleh organisasi. Kegagalan dalam pencapaian kinerja pada kepolisian dapat berdampak besar, seperti halnya dengan hilangnya kepercayaan masyarakat terhadap Polri. Penelitian terdahulu yang dilakukan oleh Sitepu (2015) menunjukkan bahwa kinerja karyawan secara parsial berpengaruh secara signifikan terhadap produktivitas kerja karyawan. Hasil penelitian tersebut menunjukkan arti pentingnya kinerja karyawan atau sumber daya manusia dalam organisasi dalam menjaga eksistensi sebuah organisasi. Sumber daya manusia berperan dalam perencanaan, pelaksanaan, pengawasan dan pengendalian organisasi agar perusahaan mencapai misi dengan baik. Produktivitas kerja bukan semata-mata ditujukan untuk mendapatkan hasil kerja sebanyakbanyaknya, melainkan kualitas untuk kerja juga penting diperhatikan. Produktivitas karyawan perlu memperhatikan usaha yang dilakukan karyawan dalam meningkatkan kemampuan profesionalnya melalui berbagai kegiatan yang berkesinambungan, dengan maksud untuk meningkatkan kemampuan dirinya sesuai dengan tuntutan tugas. Harapan pencapaian kinerja maksimal pada anggota Polri nampaknya belum sepenuhnya dapat terlaksana, karena pada Ditlantas Polda Jateng masih terdapat bentuk ketidakmaksimal pencapaian target kerja.

Pada dasarnya, setiap SDM memiliki potensi untuk memberikan kontribusi yang produktif bagi organisasi dan potensi tersebut harus direalisir secara optimal. Itulah sebabnya, kuantitas dan terutama kualitas SDM merupakan faktor penentu bagi keberhasilan pelaksanaan tugas-tugas yang dipercayakan kepada Polri. Pengembangan SDM merupakan sesuatu yang sangat penting dalam mewujudkan paradigma baru Polri, sebagai organisasi sipil yang melindungi dan bukan lagi sebagai pengendali masyarakat. Hal itu sesuai dengan tuntutan masyarakat nasional dan global terhadap institusi kepolisian yaitu mandiri, akuntabel dan kompeten. Mengantisipasi tuntutan tersebut, diperlukan strategi pengembangan SDM yang efektif dan efisien, guna mewujudkan sosok Polri yang diharapkan semua pihak terutama harapan masyarakat.

Torang (2013) mengemukakan bahwa faktor yang memengaruhi kinerja, salah satu diantaranya adalah faktor organisasi, yaitu reward. Salah satu bentuk perhatian suatu instansi terhadap para pegawai yaitu dengan menerapkan suatu strategi pemberian kompensasi dalam bentuk remunerasi, hal ini dilakukan guna memacu kinerja dari para pegawainya. Apabila dilihat lebih mendalam permasalahan kinerja yang dialami Ditlantas Polda Jateng terkait dengan remunerasi yang diterimanya. Remunerasi merupakan salah satu fungsi yang penting dalam manajemen sumber daya manusia (MSDM), karena remunerasi merupakan salah satu aspek yang paling sensitif di dalam hubungan kerja. Remunerasi yang sesuai dengan harapan anggota Ditlantas Polda Jateng dapat semakin menunjang pencapaian kinerja maksimal.

Gustika (2013) menyimpulkan hasil penelitiannya bahwa remunerasi berpengaruh signifikan terhadap kinerja anggota Polri Polres Pasaman. Untuk meningkatkan kinerja pemerintah telah menyetujui pemberian tunjangan kinerja atau Remunerasi bagi pegawai dilingkungan Polri. Bagi polri tunjangan kinerja itu merupakan hal positif untuk peningkatan kinerja. Pemberian tunjangan pada Kepolisian didasarkan pada Peraturan Presiden Nomor 73 tahun 2010 tentang Tunjangan Kinerja Pegawai di Lingkungan Kepolisian. Tunjangan itu diberikan dalam 18 kelas Jabatan sesuai dengan kepangkatan. Pemberian tunjangan Polri dapat menghindarkan anggota Polri dari praktik-praktik yang menyimpang, seperti korupsi. Bagi anggota Ditlantas Polda Jateng tunjangan kinerja itu merupakan hal positif untuk peningkatan kinerja. 
Kinerja anggota organisasi juga terkait dengan kepuasan kerja. Sebagaimana pendapat Podsakoff (2000) bahwa ada empat faktor yang mendorong munculnya OCB dalam diri karyawan. Salah satu dari keempat faktor tersebut adalah karakteristik individual, karakteristik tugas/pekerjaan, karakteristik organisasional dan perilaku pemimpin. Karakteristik individu ini meliputi kepuasan kerja. Penelitian terdahulu yang dilakukan oleh Nurizki (2015) berpendapat bahwa terdapat pengaruh kepuasan kerja terhadap kinerja Polisi Lalu Lintas di Polresta Bogor. Hasil penelitian tersebut bertolak belakang dengan penelitian yang dilakukan oleh Agustiningsih, dkk (2016) yang menunjukkan bahwa kepuasan kerja tidak berpengaruh terhadap kinerja.

Faktor lain yang diduga berpengaruh terhadap kinerja anggota BPKB Ditlantas Polda Jateng adalah kepemimpinan, salah satunya adalah kepemimpinan transformasional. Kepemimpinan transformasional ditandai dengan interaksi antara pemimpin dan pengikutnya, manajer dengan bawahannya oleh pengaruh pimpinan atau manajer untuk mengubah perilaku pengikut atau bawahannya menjadi seseorang yang merasa mampu dan bermotivasi tinggi, serta berupaya mencapai prestasi kerja yang tinggi dan bermutu (Munandar, 2012).

Penelitian terdahulu yang dilakukan oleh Subhi (2014) menunjukkan bahwa gaya kepemimpinan transformasional secara simultan berpengaruh signifikan terhadap kinerja karyawan PT Telkomsel Metro Surabaya. Anggota BPKB Ditlantas Polda Jateng yang memersepsikan secara positif cara-cara atasan dalam menggunakan kekuasaan untuk mengarahkan pekerjaan sebagai kepemimpinan transformasional, akan menjadikan anggota BPKB Ditlantas Polda Jateng merasa bangga dengan keberadaan atasan. Anggota BPKB Ditlantas Polda Jateng akan merasakan kenyamanan dalam bekerja dan berusaha mengerahkan usahanya untuk mencapai target kerja, karena atasan dapat memberikan dorongan kepada bawahan. Persepsi positif terhadap kepemimpinan transformasional atasan, maka akan mendorong munculnya perilaku kerja positif, seperti halnya dengan tercapainya kinerja yang maksimal.

Pengaruh remunerasi, kepuasan kerja dan kepemimpinan transformasional akan lebih kuat dengan terbentuknya organizational citizenship bahaviour pada anggota BPKB Ditlantas Polda Jateng. Organizational citizenship bahaviour sangat diperlukan untuk mencapai peningkatan kinerja karyawan yang lebih baik. Penelitian yang dilakukan Supriyanto dan Triyanto (2014) juga menunjukkan bahwa organizational citizenship bahaviour memediasi secara penuh (Full Mediation) pengaruh antara kepuasan kerja pada kinerja karyawan. Organizational citizenship bahaviour juga memediasi sebagian (Partial Mediation) pengaruh antara kepemimpinan transformasional pada kinerja karyawan. Akan tetapi, terkait dengan pengaruh kepuasan kerja terhadap organizational citizenship bahaviour masih terdapat kesenjangan, dimana penelitian terdahulu yang dilakukan oleh Hendarto (2013) menunjukkan bahwa terdapat pengaruh yang cukup kuat dan signifikan antara kepuasan kerja terhadap organizational citizenship bahaviour. Sedangkan penelitian yang dilakukan oleh Ningsih dan Arsanti (2014) yang justru menunjukkan bahwa job satisfaction tidak berpengaruh terhadap organizational citizen behavior.

Selain itu terdapat pula research gap dari penelitian terdahulu terkait pengaruh kepemimpinan transformasional terhadap organizational citizen behavior. Gunawan (2016) menyimpulkan hasil penelitiannya bahwa terdapat hubungan positif yang kuat antara kepemimpinan transformasional terhadap organizational citizenship behavior. Hasil penelitian tersebut bertolak belakang dengan temuan penelitian Arifiani, dkk (2016) yang menyimpulkan bahwa kepemimpinan transformasional tidak memiliki 
pengaruh signifikan terhadap organizational citizenship behavior. Begitu juga halnya Purwaningsih dan Liana (2016) yang juga menyimpulkan penelitiannya bahwa kepemimpinan transformasional tidak berpengaruh terhadap organizational citizenship behavior.

Berdasarkan uraian latar belakang peneliti merumuskan permasalahan, yaitu "bagaimana meningkatkan kinerja pegawai dengan organizational citizen behavior sebagai variabel intervening pada seksi BPKB Ditlantas Polda Jateng?". Berdasarkan rumusan masalah tersebut dapat dikembangkan pertanyaan penelitian sebagai berikut :

1. Bagaimana pengaruh remunerasi terhadap organizational citizen behavior?

2. Bagaimana pengaruh kepuasan kerja terhadap organizational citizen behavior?

3. Bagaimana pengaruh kepemimpinan transformasional terhadap organizational citizen behavior?

4. Bagaimana pengaruh remunerasi terhadap kinerja anggota BPKB Polda Jateng?

5. Bagaimana pengaruh remunerasi terhadap kinerja anggota BPKB Polda Jateng?

6. Bagaimana pengaruh kepemimpinan transformasional terhadap kinerja anggota BPKB Polda Jateng?

7. Bagaimana pengaruh organizational citizen behavior terhadap kinerja anggota BPKB Polda Jateng?

\section{TELAAH PUSTAKA}

\section{Hubungan antara Remunerasi dengan Organizational Citizen Behavior}

Sutrisno (2009) menyatakan bahwa kompensasi merupakan salah satu fungsi yang penting dalam manajemen sumber daya manusia (MSDM), karena kompensasi merupakan salah satu aspek yang paling sensitif di dalam hubungan kerja. Salah satu bentuk kompensasi yang diterima oleh pegawai dalam bekerja adalah remunerasi. Remunerasi merupakan salah satu fungsi yang penting dalam manajemen sumber daya manusia (MSDM), karena remunerasi merupakan salah satu aspek yang paling sensitif di dalam hubungan kerja. Remunerasi yang sesuai dengan harapan anggota BPKB Dilantas Polda Jateng dapat semakin menjadikan anggota BPKB Dilantas Polda Jateng menunjukkan Organizational Citizenship Behavior.

Tan dan Tarigan (2017) menyimpulkan hasil penelitiannya bahwa kompensasi berpengaruh terhadap Organizational Citizenship Behavior (OCB). Begitu juga halnya dengan Fitrianasari, dkk (2013) yang menyimpulkan hasil penelitiannya bahwa ompensasi finansial maupun non financial yang dirasakan sesuai dengan harapan perawat akan dapat menguatkan Organizational Citizenship Behavior (OCB) perawat. Mengacu pada uraian tersebut maka dapat dirumuskan hipotesis sebagai berikut:

H1 : Remunerasi berpengaruh positif terhadap organizational citizen behavior.

\section{Hubungan antara Kepuasan Kerja dengan Organizational Citizen Behavior}

Meningkatnya perilaku Organizational Citizenship Behavior dipengaruhi oleh dua faktor utama, yaitu faktor yang berasal dari dalam diri karyawan (internal) seperti moral, rasa puas, sikap positif dan lain sebagainya. Sedangkan faktor yang berasal dari luar karyawan (eksternal) seperti sistem manajemen, sistem kepemimpinan dan budaya perusahaan. Hal ini senada dengan pendapat Podsakoff (2000) bahwa ada empat faktor yang mendorong munculnya OCB dalam diri karyawan. Salah satu dari keempat faktor tersebut adalah karakteristik individual, karakteristik tugas/pekerjaan, karakteristik organisasional dan perilaku pemimpin. Karakteristik individu ini meliputi kepuasan kerja. 
Penting untuk menjaga agar pegawai dapat merasakan kepuasan sehingga pegawai dapat menunjukkan produktivitas yang baik dalam bekerja. Penelitian terdahulu yang dilakukan oleh Hendarto (2013) menunjukkan bahwa terdapat pengaruh yang cukup kuat dan signifikan antara kepuasan kerja terhadap organizational citizenship bahavior. Fitrianasari, dkk (2013) menyimpulkan hasil penelitiannya bahwa perasaan senang atas pembayaran, pekerjaan, proses promosi, kondisi lingkungan kerja serta rekan kerja yang mencerminkan kepuasan kerja perawat akan menguatkan Organizational Citizenship Behavior $(O C B)$ perawat perawat.

Penelitian tersebut sejalan dengan hasil penelitian yang dilakukan Rohayati (2014) yang menunjukkan bahwa terdapat pengaruh yang signifikan antara kepuasan kerja terhadap $O C B$ Karyawan YMMI. Hal ini berarti peningkatan kepuasan kerja akan meningkatkan secara signifikan Organizational Citizenship Behavior karyawan YMMI Bandung. Arifiani, dkk (2016) juga menyimpulkan hasil penelitiannya bahwa kepuasan kerja memiliki pengaruh signifikan terhadap Organizational Citizenship Behavior. Mengacu pada uraian tersebut maka dapat dirumuskan hipotesis sebagai berikut:

$\mathrm{H} 2$ : Kepuasan kerja berpengaruh positif terhadap organizational citizen behavior.

\section{Hubungan antara Kepemimpinan Transformasional dengan Organizational Citizen Behavior}

Podsakoff (2000) menyatakan bahwa faktor lain yang mendorong munculnya $O C B$ dalam diri karyawan, adalah karakteristik organisasional salah satunya adalah model kepemimpinan. Munandar (2001) menyatakan bahwa secara garis besar terdapat beberapa corak interaksi pimpinan dengan bawahannya, yaitu kepemimpinan transaksional dan kepemimpinan transformasional. Seorang pemimpin harus dapat mentransformasikan visi dan misi perusahaan kepada bawahan dan menyamakan visi mereka dengan visi bawahan. Model kepemimpinan yang mampu mentransformasikan visi dan misi perusahaan kepada bawahan disebut dengan kepemimpinan transformasional sebagai kepemimpinan baru (the new leadership), sedangkan Bass (1996) menyebutnya sebagai pemimpin penerobos (breakhthrough leadership).

Kepemimpinan transformasional akan menjadikan karyawan merasakan kenyamanan dan kepuasan dalam bekerja dengan kehadiran pimpinan, sehingga karyawan dengan sendirinya akan menunjukkan organizational citizen behavior. Sebagaimana hasil penelitian terdahulu yang dilakukan oleh Gunawan (2016) yang menunjukkan bahwa terdapat hubungan positif yang kuat antara kepemimpinan transformasional terhadap organizational citizenship behavior. Lebih lajut Zulbadi, dkk (2016) juga menyimpulkan bahwa kepemimpinan transformasional berpengaruh positif dan signifikan terhadap OCB karyawan secara parsial. Mengacu pada uraian tersebut maka dapat dirumuskan hipotesis sebagai berikut:

H3 : Kepemimpinan transformasional berpengaruh positif terhadap organizational citizen behavior.

\section{Hubungan antara Remunerasi dengan Kinerja Anggota BPKB Ditlantas Polda Jateng}

Torang (2013) mengemukakan bahwa faktor yang memengaruhi kinerja, salah satu diantaranya adalah faktor organisasi, yaitu reward yang diterima oleh karyawan. Sebuah instansi dituntut untuk mengembangkan cara baru untuk mempertahankan pegawai pada produktifitas tinggi serta mengembangkan potensinya agar memberikan kontribusi maksimal pada instansi atau organisasi tersebut. Salah satu bentuk perhatian 
suatu instansi terhadap para pegawai yaitu dengan menerapkan suatu strategi pemberian kompensasi dalam bentuk remunerasi, hal ini dilakukan guna memacu kinerja dari para pegawainya. Penelitian terdahulu yang dilakukan oleh Wilfred, Elijah, dan Muturi (2014) menunjukkan bahwa Pemberian remunerasi berpengaruh secara positif terhadap kinerja pegawai di Kementerian Keamanan Internal.

Hasil penelitian terdahulu yang dilakukan oleh Gustika (2013) menunjukkan bahwa remunerasi berpengaruh signifikan terhadap kinerja anggota Polri Polres Pasaman. Untuk meningkatkan kinerja pemerintah telah menyetujui pemberian tunjangan kinerja atau Remunerasi bagi pegawai dilingkungan Polri. Bagi polri tunjangan kinerja itu merupakan hal positif untuk peningkatan kinerja. Pemberian tunjangan pada Kepolisian didasarkan pada Peraturan Presiden Nomor 73 tahun 2010 tentang Tunjangan Kinerja Pegawai di Lingkungan Kepolisian. Tunjangan itu diberikan dalam 18 kelas Jabatan sesuai dengan kepangkatan. Pemberian tunjangan Polri dapat menghindarkan anggota Polri dari praktik-praktik yang menyimpang, seperti korupsi. Bagi anggota BPKB Ditlantas Polda Jateng, tunjangan kinerja itu merupakan hal positif untuk peningkatan kinerja. Lebih lanjut Aziz dan Niswah (2016) yang menyimpulkan hasil penelitiannya bahwa remunerasi berpengaruh positif dan signifikan terhadap kinerja pegawai Kantor Pelayanan Pajak Pratama Tuban. Mengacu pada uraian tersebut maka dapat dirumuskan hipotesis sebagai berikut:

H4 : Remunerasi berpengaruh positif terhadap kinerja anggota BPKB Ditlantas Polda Jateng.

\section{Hubungan antara Kepuasan Kerja dengan Kinerja Anggota BPKB Ditlantas Polda Jateng}

Kepuasan kerja adalah suatu tingkat emosi yang positif dan menyenangkan individu. Dengan kata lain, kepuasan kerja adalah suatu hasil pemikiran individu terhadap pekerjaan atau pengalaman yang positif dan menyenangkan dirinya. Kepuasan kerja dapat dilihat dari segi moral dan keterlibatan kerja. Kepuasan kerja dikategorikan moral dan kepuasan kerja sebagai suatu emosi positif yang akan dilalui oleh karyawan. Kepuasan kerja memiliki peran penting bagi peningkatan kinerja anggota BPKB Ditlantas Polda Jateng.

Sebagaimana penelitian terdahulu yang dilakukan oleh Nurizki (2015) menunjukkan bahwa terdapat pengaruh antara kepuasan kerja terhadap persepsi kinerjanya polisi lalu lintas di Polresta Bogor. Lebih lanjut Susanti dan Palupiningdyah (2016) juga menyimpulkan hasil penelitiannya bahwa kepuasan kerja berpengaruh positif dan signifikan terhadap kinerja karyawan. Mengacu pada uraian tersebut maka dapat dirumuskan hipotesis sebagai berikut:

H5 : Kepuasan kerja berpengaruh positif terhadap kinerja anggota BPKB Ditlantas Polda Jateng.

\section{Hubungan antara Kepemimpinan Transformasional dengan Kinerja Anggota BPKB Ditlantas Polda Jateng}

Kepemimpinan merupakan salah satu faktor penting yang berkaitan dengan pencapaian kinerja organisasi. Kepemimpinan transformasional berbeda dengan kepemimpinan transaksional dalam dua hal. Pertama, pemimpin transformasional bertindak efektif, karena mengenali kebutuhan bawahan. Berbeda dengan kepemimpinan transaksional yang bertindak aktif. Kedua, pemimpin transformasional yang efektif berusaha menaikkan kebutuhan bawahan sehingga, dapat memotivasi kerja 
dan mendorong bawahan untuk lebih maju dalam pencapaian kinerja. Bukti empiris menunjukkan bahwa, kepemimpinan transformasional berpengaruh terhadap efektifitas organisasi dan kinerja karyawan (Walter, 1998). Lebih lanjut, hasil penelitian Muhdiyanto (2016) menunjukkan bahwa kepemimpinan transformasional berpengaruh positif terhadap kinerja karyawan. Bana (2015) juga menyimpulkan hasil penelitiannya bahwa kepemimpinan transformasional dapat meningkatkan kinerja pegawai Kantor PDAM Kota Kendari. Peran pemimpin dalam suatu perusahaan sangat menentukan arah dan tingkat pencapaian suatu organisasi. Kepemimpinan transfor-masional yang menekankan peran pemimpin sebagai panutan bagi pegawai, menjadi inspirasi dan motivasi bagi pegawai serta membimbing pegawai dalam pelaksanaan tugas sehari-hari akan membantu pegawai dalam peningkatan kinerja pegawai tersebut. Mengacu pada uraian tersebut maka dapat dirumuskan hipotesis sebagai berikut:

H6 : Kepemimpinan transformasional berpengaruh positif terhadap kinerja anggota BPKB Ditlantas Polda Jateng.

\section{Hubungan antara Organizational Citizen Behavior dengan Kinerja Anggota BPKB Ditlantas Polda Jateng}

Organizational citizenship behavior $(O C B)$ dianggap sebagai suatu perilaku di tempat kerja yang sesuai dengan penilaian pribadi yang melebihi persyaratan kerja dasar seseorang. OCB juga dapat dijelaskan sebagai perilaku yang melebihi permintaan tugas.

Penelitian terdahulu yang dilakukan oleh Chelagat, dkk (2015) menunjukkan bahwa organizational citizen behavior merupakan faktor penting dalam kinerja karyawan. Penelitian lain yang dilakukan oleh Ratnasari (2010) menunjukkan bahwa organizational citizen behavior terdiri dari kepatuhan, partisipasi, dan loyalitas memiliki pengaruh terhadap kinerja personil Poltabes Barelang. Faktor yang paling dominan berpengaruh terhadap kinerja personil Poltabes Barelang adalah partisipasi. Putri dan Utami (2017) juga menyimpulkan hasil penelitiannya bahwa secara simultan (bersama-sama) pada setiap variabel bebas yang merupakan dimensi organizational citizen behavior menunjukan variabel Altruism (X1), Conscientiousnes (X2), Sportsmanship (X3), Courtesy (X4), Civic virtue (X5) mempunyai pengaruh yang signifikan secara simultan terhadap kinerja karyawan. Mengacu pada uraian tersebut maka dapat dirumuskan hipotesis sebagai berikut:

H7 : Organizational citizen behavior berpengaruh positif terhadap kinerja anggota BPKB Ditlantas Polda Jateng.

\section{METODE}

Dalam penelitian ini peneliti menggunakan pendekatan penelitian kuantitatif. Data yang digunakan dalam penelitian ini adalah data primer, yaitu data diperoleh secara langsung dengan membagi kuesioner atau daftar pertanyaan kepada anggota bagian BPKB Ditlantas Polda Jateng. Peneliti menggunakan semua anggota populasi sebagai sampel yang berjumlah 50 orang. Teknik pengumpulan data dalam penelitian ini dengan kuesioner yang disusun dengan menurunkan beberapa aspek yang terkait dengan variabel penelitian. Teknik analisis data yang digunakan, meliputi uji validitas dan reliabilitas, analisis deskriptif, analisis regresi linier berganda, uji-t, analisis jalur, sobeltest, dan koefisien determinasi. 


\section{HASIL DAN PEMBAHASAN}

\section{Deskripsi tentang Remunerasi (X1)}

Berdasarkan analisis deskriptif diketahui bahwa rata-rata variabel remunerasi berada pada kategori rendah. Rendahnya variabel remunerasi dapat diartikan bahwa anggota bagian BPKB Ditlantas Polda Jateng masih merasa bahwa remunerasi yang diterima belum sesuai dengan harapan dan tanggungjawab yang dilakukannya. Indikator tertinggi terletak pada indikator pertama, yaitu besarnya remunerasi sudah layak berada pada kategori tinggi dengan rata-rata sebesar 38.2. Indikator terendah terletak pada indikator ketiga, yaitu remunerasi telah diberikan sesuai tanggungjawab anggota dengan rata-rata sebesar 14.4 atau dalam kategori rendah.

\section{Deskripsi tentang Kepuasan Kerja (X2)}

Berdasarkan analisis deskriptif diketahui bahwa rata-rata variabel kepuasan kerja berada pada kategori sedang, yaitu sebesar 24.38. Kepuasan kerja yang tergolong sedang berarti anggota bagian BPKB Ditlantas Polda Jateng cukup merasakan adanya kepuasan dengan karakteristik pekerjaan ataupun lingkungan kerjanya. Indikator tertinggi terletak pada indikator ketujuh, yaitu anggota memiliki kesempatan menduduki jabatan tertentu dalam organisasi berada pada kategori sedang dengan rata-rata sebesar 27.4. Indikator terendah terletak pada indikator pertama, yaitu kemampuan yang saya miliki meningkat dengan bekerja di organisasi Kepolisian dengan rata-rata sebesar 20.2 atau dalam kategori rendah.

\section{Deskripsi tentang Kepemimpinan Transformasional (X3)}

Berdasarkan analisis deskriptif diketahui bahwa rata-rata variabel kepemimpinan transformasional berada pada kategori sedang, yaitu sebesar 24.5. Kepemimpinan transformasional yang tergolong sedang berarti anggota bagian BPKB Ditlantas Polda Jateng menganggap sosok pimpinan cukup dapat menerapkan gaya kepemimpinan yang memotivasi ataupun sebagai seorang yang dapat memberikan inspirasi bagi anggota. Indikator tertinggi terletak pada indikator kedelapan, yaitu saya nyaman dengan nasehat yang diberikan atasan berada pada kategori sedang dengan rata-rata sebesar 27.6. Indikator terendah terletak pada indikator kedua, yaitu atasan percaya terhadap langkah yang saya lakukan dalam bekerja dengan rata-rata sebesar 19 atau dalam kategori rendah.

\section{Deskripsi tentang $O C B$ (Y1)}

Berdasarkan analisis deskriptif diketahui bahwa rata-rata variabel $O C B$ berada pada kategori sedang, yaitu sebesar 33.58. $O C B$ yang berada pada kategori sedang merupakan hal yang harus ditingkatkan oleh Ditlantas Polda Jateng, karena sebagai aparatur pelayan masyarakat, anggota dituntut untuk menunjukkan $O C B$ yang tinggi, sehingga merasa menjadi bagian dari organisasi dan bekerja optimal dengan kemajuan organisasi. Indikator tertinggi terletak pada indikator pertama, yaitu demi kelancaran pekerjaan, saya rela menjelaskan cara kerja yang efektif kepada rekan kerja berada pada kategori sedang dengan rata-rata sebesar 34.6. Indikator terendah terletak pada indikator keenam, yaitu saya bersedia mengikuti kejuruan ataupun pelatihan yang menunjang pekerjaan dengan rata-rata sebesar 32.2 atau dalam kategori sedang. 


\section{Deskripsi tentang Kinerja Anggota Bagian BPKB Ditlantas Polda Jateng (Y2)}

Berdasarkan analisis deskriptif diketahui bahwa rata-rata variabel kinerja anggota bagian BPKB Ditlantas Polda Jateng berada pada kategori tinggi, yaitu sebesar 41.2. Kinerja yang tergolong tinggi menunjukkan kemampuan anggota bagian BPKB Ditlantas Polda Jateng mengaplikasikan kemampuan yang dimiliki dalam memberikan pelayanan kepada masyarakat. Indikator tertinggi terletak pada indikator ketiga, yaitu saya menjadikan target pelayanan BPKB sebagai tanggung jawab utama berada pada kategori tinggi dengan rata-rata sebesar 46. Indikator terendah terletak pada indikator kedua, yaitu peralatan di kantor menunjang pelaksanaan tugas dengan rata-rata sebesar 37.4 atau dalam kategori tinggi.

\section{Analisis Regresi Linier Berganda}

Analisis regresi dilakukan dengan mendasarkan pada nilai standardized coefficients dari masing-masing variabel yang diteliti. Hasil perhitungan analisis regresi berganda dapat dilihat pada tabel 1 di bawah ini.

Tabel 1

Hasil Analisis Regresi Berganda

\begin{tabular}{|c|c|c|c|c|}
\hline & $\begin{array}{c}\text { Standardized } \\
\text { Coefficients } \\
\text { Beta }\end{array}$ & $\mathbf{t}$ & Sig & Ket. \\
\hline Persamaan Regresi I & & & & \\
\hline Remunerasi & 0,264 & 2,425 & 0,019 & $<0.05$ \\
\hline Kepuasan kerja & 0,379 & 2,865 & 0,006 & $<0.05$ \\
\hline $\begin{array}{c}\text { Kepemimpinan } \\
\text { transformasional }\end{array}$ & 0,276 & 2,057 & 0,045 & $<0.05$ \\
\hline Persamaan Regresi II & & & & \\
\hline Remunerasi & 0,462 & 5,683 &, 000 & $<0.05$ \\
\hline Kepuasan kerja & 0,226 & 2,236 &, 030 & $<0.05$ \\
\hline $\begin{array}{c}\text { Kepemimpinan } \\
\text { transformasional }\end{array}$ & 0,260 & 2,643 &, 011 & $<0.05$ \\
\hline $\begin{array}{c}\text { organizational citizen } \\
\text { behavior }\end{array}$ & 0,220 & 2,126 &, 039 & $<0.05$ \\
\hline
\end{tabular}

Sumber : data primer yang diolah 2018

Berdasarkan tabel 1 tersebut hasil uji t terlihat variabel remunerasi, kepuasan kerja, kepemimpinan transformasional, dan organizational citizen behavior berpengaruh positif terhadap kinerja anggota BPKB Ditlantas Polda Jateng dengan signifikan $<0,05$. Dari tabel tersebut juga dapat dibuat persamaan matematis sebagai berikut:

$\hat{\mathrm{Y}}_{1}=0,264 \mathrm{X} 1+0,379 \mathrm{X} 2+0,276 \mathrm{X} 3$

$\hat{\mathrm{Y}}_{2}=0,462 \mathrm{X} 1+0,226 \mathrm{X} 2+0,260 \mathrm{X} 3+0,220 \mathrm{Y} 1$

Keterangan:

$\hat{\mathrm{Y}}_{1}=O C B$

$\hat{\mathrm{Y}}_{2}=$ Kinerja anggota bagian BPKB Ditlantas Polda Jateng

$\mathrm{X} 1$ = Remunerasi

$\mathrm{X} 2$ = Kepuasan kerja

$\mathrm{X} 3$ = Kepemimpinan transformasional 
1. Nilai koefisien regresi dari variabel remunerasi pada persamaan 1 sebesar 0,264 memiliki arah positif. Hal tersebut berarti apabila remunerasi mengalami peningkatan satu satuan, maka nilai $O C B$ akan semakin meningkat dengan asumsi variabel bebas yang lain nilainya tetap.

2. Nilai koefisien regresi dari variabel kepuasan kerja pada persamaan 1 sebesar 0,379 memiliki arah positif. Hal tersebut berarti apabila kepuasan kerja mengalami peningkatan satu satuan, maka nilai $O C B$ akan semakin meningkat dengan asumsi variabel bebas yang lain nilainya tetap.

3. Nilai koefisien regresi dari variabel kepemimpinan transformasional pada persamaan 1 sebesar 0,276 memiliki arah positif. Hal tersebut berarti apabila motivasi intrinsik mengalami peningkatan satu satuan, maka nilai kinerja SDM akan semakin meningkat dengan asumsi variabel bebas yang lain nilainya tetap.

4. Nilai koefisien regresi dari variabel remunerasi pada persamaan 2 sebesar 0,462 memiliki arah positif. Hal tersebut berarti apabila remunerasi mengalami peningkatan satu satuan, maka nilai kinerja anggota bagian BPKB Ditlantas Polda Jateng akan semakin meningkat dengan asumsi variabel bebas yang lain nilainya tetap.

5. Nilai koefisien regresi dari variabel kepuasan kerja pada persamaan 2 sebesar 0,226 memiliki arah positif. Hal tersebut berarti apabila kepuasan kerja mengalami peningkatan satu satuan, maka nilai kinerja anggota bagian BPKB Ditlantas Polda Jateng akan semakin meningkat dengan asumsi variabel bebas yang lain nilainya tetap.

6. Nilai koefisien regresi dari variabel kepemimpinan transformasional pada persamaan 2 sebesar 0,260 memiliki arah positif. Hal tersebut berarti apabila kepemimpinan transformasional mengalami peningkatan satu satuan, maka nilai kinerja anggota bagian BPKB Ditlantas Polda Jateng akan semakin meningkat dengan asumsi variabel bebas yang lain nilainya tetap.

7. Nilai koefisien regresi dari variabel $O C B$ pada persamaan 2 sebesar 0,220 memiliki arah positif. Hal tersebut berarti apabila $O C B$ mengalami peningkatan satu satuan, maka nilai kinerja anggota bagian BPKB Ditlantas Polda Jateng akan semakin meningkat dengan asumsi variabel bebas yang lain nilainya tetap.

\section{Uji Hipotesis (Uji-t)}

Uji parsial atau uji t dilakukan untuk mengetahui pengaruh variabel independen (X) terhadap variabel dependen (Y). Hasil analisis uji parsial persamaan I dan persamaan II dalam penelitian ini dapat dilihat berdasarkan tabel berikut ini:

\section{Tabel 2}

Uji-t

\begin{tabular}{|c|c|c|c|c|}
\hline & t-hitung & t-tabel & Sig & Ket. \\
\hline Persamaan Regresi I & & & & \\
\hline Remunerasi & 2,425 & 2.013 & 0,019 & $<0.05$ \\
\hline Kepuasan kerja & 2,865 & 2.013 & 0,006 & $<0.05$ \\
\hline Kepemimpinan transformasional & 2,057 & 2.013 & 0,045 & $<0.05$ \\
\hline Persamaan Regresi II & & & & \\
\hline Remunerasi & 5,683 & 2.013 & 0,000 & $<0.05$ \\
\hline Kepuasan kerja & 2,236 & 2.013 & 0,030 & $<0.05$ \\
\hline Kepemimpinan transformasional & 2,643 & 2.013 & 0,011 & $<0.05$ \\
\hline OCB & 2,126 & 2.013 & 0,039 & $<0.05$ \\
\hline
\end{tabular}


1. Pengujian Hipotesis $1(\mathrm{H} 1)$

Berdasarkan hasil pengujian hipotesis (uji t) variabel remunerasi diperoleh nilai t-hitung sebesar 2,425 dengan nilai signifikansi sebesar 0,019 $(<0,05)$. Nilai t-hitung lebih besar dibandingkan nilai t-tabel $(2,425>2,013)$ dan nilai signifikan lebih kecil dari 0,05 , sehingga dapat disimpulkan bahwa remunerasi berpengaruh positif terhadap organizational citizen behavior atau $\mathbf{H 1}$ diterima.

2. Pengujian Hipotesis $2(\mathrm{H} 2)$

Berdasarkan hasil pengujian hipotesis (uji t) variabel kepuasan kerja diperoleh nilai t-hitung sebesar 2,865 dengan nilai signifikansi sebesar 0,006 $(<0,05)$. Nilai thitung lebih besar dibandingkan nilai t-tabel $(2,865>2,013)$ dan nilai signifikan lebih kecil dari 0,05, sehingga dapat disimpulkan bahwa kepuasan kerja berpengaruh positif terhadap organizational citizen behavior atau $\mathbf{H 2}$ diterima.

3. Pengujian Hipotesis 3 (H3)

Berdasarkan hasil pengujian hipotesis (uji t) variabel kepemimpinan transformasional diperoleh nilai t-hitung sebesar 2,057 dengan nilai signifikansi sebesar 0,045 $(<0,05)$. Nilai t-hitung lebih besar dibandingkan nilai t-tabel $(2,057>$ $2,013)$ dan nilai signifikan lebih kecil dari 0,05 , sehingga dapat disimpulkan bahwa kepemimpinan transformasional berpengaruh positif terhadap organizational citizen behavior atau $\mathbf{H 3}$ diterima.

4. Pengujian Hipotesis 4 (H4)

Berdasarkan hasil pengujian hipotesis (uji t) variabel remunerasi diperoleh nilai t-hitung sebesar 5,683 dengan nilai signifikansi sebesar 0,000 $(<0,05)$. Nilai t-hitung lebih besar dibandingkan nilai t-tabel $(5,683>2,013)$ dan nilai signifikan lebih kecil dari 0,05 , sehingga dapat disimpulkan bahwa remunerasi berpengaruh positif terhadap kinerja anggota BPKB Ditlantas Polda Jateng atau H4 diterima.

5. Pengujian Hipotesis 5 (H5)

Berdasarkan hasil pengujian hipotesis (uji t) variabel kepuasan kerja diperoleh nilai t-hitung sebesar 2,236 dengan nilai signifikansi sebesar 0,030 $(<0,05)$. Nilai thitung lebih besar dibandingkan nilai t-tabel $(2,236>2,013)$ dan nilai signifikan lebih kecil dari 0,05, sehingga dapat disimpulkan bahwa kepuasan kerja berpengaruh positif terhadap kinerja anggota BPKB Ditlantas Polda Jateng atau H5 diterima.

6. Pengujian Hipotesis 6 (H6)

Berdasarkan hasil pengujian hipotesis (uji t) variabel kepemimpinan transformasional diperoleh nilai t-hitung sebesar 2,643 dengan nilai signifikansi sebesar $0,011(<0,05)$. Nilai t-hitung lebih besar dibandingkan nilai t-tabel $(2,643>$ $2,013)$ dan nilai signifikan lebih kecil dari 0,05, sehingga dapat disimpulkan bahwa kepemimpinan transformasional berpengaruh positif terhadap kinerja anggota BPKB Ditlantas Polda Jateng atau H6 diterima.

7. Pengujian Hipotesis 7 (H7)

Berdasarkan hasil pengujian hipotesis (uji t) variabel organizational citizen behavior diperoleh nilai t-hitung sebesar 2,126 dengan nilai signifikansi sebesar $0,039(<0,05)$. Nilai t-hitung lebih besar dibandingkan nilai t-tabel $(2,126>2,013)$ 
dan nilai signifikan lebih kecil dari 0,05, sehingga dapat disimpulkan bahwa organizational citizen behavior berpengaruh positif terhadap kinerja anggota BPKB Ditlantas Polda Jateng atau $\mathbf{H 7}$ diterima.

\section{Koefisien Determinasi}

Untuk mengetahui persentase pengaruh variabel independen terhadap variabel dependen digunakan koefisien determinan dilihat pada tabel berikut:

Tabel 3

Koefisien Determinasi

\begin{tabular}{|c|c|}
\hline & \multirow{2}{*}{$\begin{array}{c}\text { Adjusted R } \\
\text { Square }\end{array}$} \\
\cline { 1 - 1 } Persamaan Regresi I & \multirow{2}{*}{0,453} \\
\cline { 1 - 1 } Remunerasi & \\
\cline { 1 - 1 } Kepuasan kerja & \\
\cline { 1 - 1 } Kepemimpinan transformasional & \\
\cline { 1 - 1 } Persamaan Regresi II & \\
\cline { 1 - 1 } Remunerasi & \\
\cline { 1 - 1 } Kepuasan kerja & \\
\cline { 1 - 1 } Organizational citizen behavior & \\
\cline { 1 - 1 } Sumber : data primer yang diolah 2018
\end{tabular}

Dari tabel 3 di atas menunjukkan dapat dihitung total $\mathrm{R}^{2}$ dengan langkah-langkah sebagai berikut:

1) Menghitung Error term (unsur gangguan/kesalahan penganggu)

$$
\begin{aligned}
\mathrm{e}_{1} & =\sqrt{1-\left(R_{1}\right)^{2}} \\
& =\sqrt{1-(0.453)^{2}} \\
& =\sqrt{0.794791} \\
& =0.892 \\
\mathrm{e}_{2} & =\sqrt{1-\left(R_{2)}\right.}{ }^{2} \\
& =\sqrt{1-(0.730)^{2}} \\
& =\sqrt{0.4671} \\
& =0.683
\end{aligned}
$$

2) Total $R^{2}$

$$
\begin{aligned}
& =1-\left(\mathrm{e}_{1}\right)^{2} \cdot\left(\mathrm{e}_{2}\right)^{2} \\
& =1-(0.892)^{2} \cdot(0.683)^{2} \\
& =1-0,371 \\
& =0,629
\end{aligned}
$$

Berdasarkan perhitungan di atas diketahui bahwa nilai total $\mathrm{R}^{2}$ sebesar 0,629 yang menunjukkan bahwa 62,9\% kinerja anggota BPKB Ditlantas Polda Jateng dapat dijelaskan oleh remunerasi, kepuasan kerja, kepemimpinan transformasional, dan organizational citizen behavior. 


\section{Analisis Jalur (Path Analysis)}

Untuk menguji pengaruh variabel intervening/mediasi digunakan metode analisis jalur (Path Analysis). Analisis jalur merupakan perluasan dari analisis regresi linear berganda, atau analisis jalur adalah penggunaan analisis regresi untuk menaksir hubungan kausalitas antar variabel (model casual) yang telah ditetapkan sebelumnya berdasarkan teori.

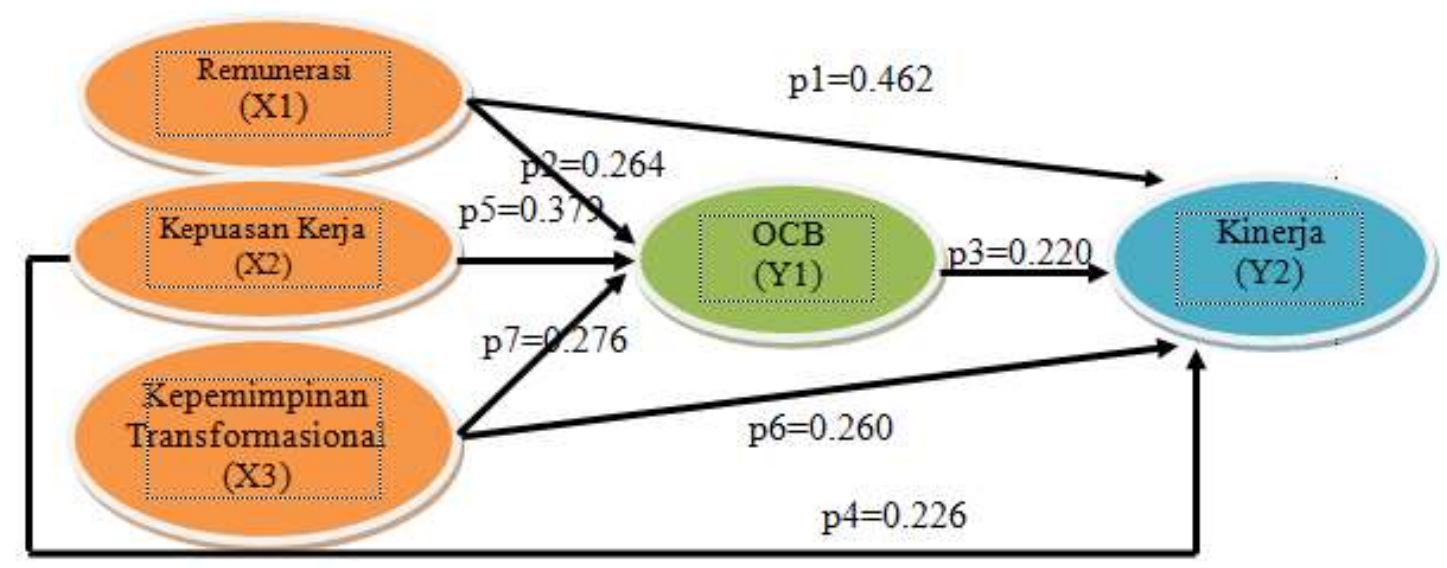

Gambar 2

Model Analisis Jalur (Path Analysis)

Berdasarkan gambar di atas diketahui bahwa pengaruh langsung remunerasi, kepuasan kerja, dan kepemimpinan transformasional terhadap kinerja anggota BPKB Ditlantas Polda Jateng lebih tinggi dibandingkan pengaruh remunerasi, kepuasan kerja, dan kepemimpinan transformasional terhadap kinerja anggota BPKB Ditlantas Polda Jateng melalui organizational citizen behavior.

\section{Pembahasan}

\section{Pengaruh Remunerasi terhadap Organizational Citizen Behavior}

Berdasarkan hasil penelitian diketahui bahwa remunerasi berpengaruh positif terhadap organizational citizen behavior yang ditunjukkan dengan taraf signifikansinya 0,019 (< 0,05). Artinya, jika remunerasi semakin baik, maka organizational citizen behavior anggota BPKB Ditlantas Polda Jateng semakin meningkat. Remunerasi yang dirasakan sesuai dengan harapan dan tanggungjawab yang diterima anggota BPKB Ditlantas Polda Jateng, akan meningkatkan perilaku kewarganeagaraan atau $O C B$ anggota BPKB Ditlantas Polda Jateng. Tan dan Tarigan (2017) menyimpulkan hasil penelitiannya bahwa kompensasi berpengaruh terhadap Organizational Citizenship Behavior (OCB). Begitu juga halnya dengan Fitrianasari, dkk (2013) yang menyimpulkan hasil penelitiannya bahwa kompensasi finansial maupun non financial yang dirasakan sesuai dengan harapan perawat akan dapat menguatkan Organizational Citizenship Behavior (OCB) perawat.

\section{Pengaruh Kepuasan Kerja terhadap Organizational Citizen Behavior}

Berdasarkan hasil penelitian diketahui bahwa kepuasan kerja berpengaruh positif terhadap organizational citizen behavior yang ditunjukkan dengan taraf signifikansinya $0,006(<0,05)$. Artinya, jika kepuasan kerja semakin baik, maka organizational citizen 
behavior anggota BPKB Ditlantas Polda Jateng semakin meningkat. Terpenuhinya kepuasan kerja pada anggota BPKB Ditlantas Polda Jateng akan semakin menjadikan anggota BPKB Ditlantas Polda Jateng menjadi bagian dalam organisasi tempatnya bertugas. Hasil tersebut sejalan dengan hasil penelitian yang dilakukan Rohayati (2014) yang menunjukkan bahwa terdapat pengaruh yang signifikan antara kepuasan kerja terhadap $O C B$ Karyawan YMMI. Hal ini berarti peningkatan kepuasan kerja akan meningkatkan secara signifikan Organizational Citizenship Behavior karyawan YMMI Bandung. Arifiani, dkk (2016) juga menyimpulkan hasil penelitiannya bahwa kepuasan kerja memiliki pengaruh signifikan terhadap Organizational Citizenship Behavior.

\section{Pengaruh Kepemimpinan Transformasional terhadap Organizational Citizen Behavior}

Berdasarkan hasil penelitian diketahui bahwa kepemimpinan transformasional berpengaruh positif terhadap organizational citizen behavior yang ditunjukkan dengan taraf signifikansinya $0,045(<0,05)$. Artinya, jika kepemimpinan transformasional semakin baik, maka organizational citizen behavior anggota BPKB Ditlantas Polda Jateng semakin meningkat. Sosok pimpinan yang dipersepsikan sebagai pemimpin transformasional dan mampu mendorong anggota BPKB Ditlantas Polda Jateng bekerja lebih baik, menjadikan anggota semakin menunjukkan $O C B$. Kepemimpinan transformasional akan menjadikan karyawan merasakan kenyamanan dan kepuasan dalam bekerja dengan kehadiran pimpinan, sehingga karyawan dengan sendirinya akan menunjukkan organizational citizen behavior. Sebagaimana hasil penelitian terdahulu yang dilakukan oleh Gunawan (2016) yang menunjukkan bahwa terdapat hubungan positif yang kuat antara kepemimpinan transformasional terhadap organizational citizenship behavior. Lebih lajut Zulbadi, dkk (2016) juga menyimpulkan bahwa kepemimpinan transformasional berpengaruh positif dan signifikan terhadap OCB karyawan secara parsial.

\section{Pengaruh Remunerasi terhadap Kinerja Anggota BPKB Ditlantas Polda Jateng}

Berdasarkan hasil penelitian diketahui bahwa remunerasi berpengaruh positif terhadap kinerja anggota BPKB Ditlantas Polda Jateng yang ditunjukkan dengan taraf signifikansinya $0,000(<0,05)$. Artinya, jika remunerasi semakin baik, maka kinerja anggota BPKB Ditlantas Polda Jateng semakin meningkat. Remunerasi yang diterima oleh anggota BPKB Ditlantas Polda Jateng memegang peranan penting bagi kinerjanya. Anggota BPKB Ditlantas Polda Jateng yang menganggap bahwa besarnya remunerasi telah sesuai dengan ketentuan, diberikan tepat waktu dan memperhatikan tanggungjawab dari anggota, dapat semakin meningkatkan kesediaan anggota bekerja secara optimal. Hasil penelitian terdahulu yang dilakukan oleh Gustika (2013) menunjukkan bahwa remunerasi berpengaruh signifikan terhadap kinerja anggota Polri Polres Pasaman. Untuk meningkatkan kinerja pemerintah telah menyetujui pemberian tunjangan kinerja atau Remunerasi bagi pegawai dilingkungan Polri. Bagi polri tunjangan kinerja itu merupakan hal positif untuk peningkatan kinerja. Pemberian tunjangan pada Kepolisian didasarkan pada Peraturan Presiden Nomor 73 tahun 2010 tentang Tunjangan Kinerja Pegawai di Lingkungan Kepolisian. Tunjangan itu diberikan dalam 18 kelas Jabatan sesuai dengan kepangkatan. Pemberian tunjangan Polri dapat menghindarkan anggota Polri dari praktik-praktik yang menyimpang, seperti korupsi. Bagi anggota BPKB Ditlantas Polda Jateng, tunjangan kinerja itu merupakan hal positif untuk peningkatan kinerja. Lebih lanjut Aziz dan Niswah (2016) yang menyimpulkan 
hasil penelitiannya bahwa remunerasi berpengaruh positif dan signifikan terhadap kinerja pegawai Kantor Pelayanan Pajak Pratama Tuban.

\section{Pengaruh Kepuasan Kerja terhadap Kinerja Anggota BPKB Ditlantas Polda Jateng}

Berdasarkan hasil penelitian diketahui bahwa kepuasan kerja berpengaruh positif terhadap kinerja anggota BPKB Ditlantas Polda Jateng yang ditunjukkan dengan taraf signifikansinya $0,030(<0,05)$. Artinya, jika kepuasan kerja semakin baik, maka kinerja anggota BPKB Ditlantas Polda Jateng semakin meningkat. Hal tersebut berarti bahwa terpenuhinya kepuasan kerja pada anggota BPKB Ditlantas Polda Jateng, dapat menjadikan anggota dengan sendirinya menunjukkan kinerja yang optimal. Sebagaimana penelitian terdahulu yang dilakukan oleh Nurizki (2015) menunjukkan bahwa terdapat pengaruh antara kepuasan kerja terhadap persepsi kinerjanya polisi lalu lintas di Polresta Bogor. Penelitian ini sejalan dengan Susanti dan Palupiningdyah (2016) juga menyimpulkan hasil penelitiannya bahwa kepuasan kerja berpengaruh positif dan signifikan terhadap kinerja karyawan.

\section{Pengaruh Kepemimpinan Transformasional terhadap Kinerja Anggota BPKB Ditlantas Polda Jateng}

Berdasarkan hasil penelitian diketahui bahwa kepemimpinan transformasional berpengaruh positif terhadap kinerja anggota BPKB Ditlantas Polda Jateng yang ditunjukkan dengan taraf signifikansinya $0,011(<0,05)$. Artinya, jika kepemimpinan transformasional kerja semakin baik, maka kinerja anggota BPKB Ditlantas Polda Jateng semakin meningkat. Kepemimpinan transformasional sebagai bentuk kepemimpinan modern yang dianggap sesuai dengan keinginan dari anggota dapat semakin mendoorng kinerja yang lebih baik dalam memberikan pelayanan kepada masyarakat. Kepemimpinan transformasional berpengaruh terhadap efektifitas organisasi dan kinerja karyawan (Walter, 1998). Lebih lanjut, hasil penelitian Muhdiyanto (2016) menunjukkan bahwa kepemimpinan transformasional berpengaruh positif terhadap kinerja karyawan. Bana (2015) juga menyimpulkan hasil penelitiannya bahwa kepemimpinan transformasional dapat meningkatkan kinerja pegawai Kantor PDAM Kota Kendari. Peran pemimpin dalam suatu perusahaan sangat menentukan arah dan tingkat pencapaian suatu organisasi. Kepemimpinan transfor-masional yang menekankan peran pemimpin sebagai panutan bagi pegawai, menjadi inspirasi dan motivasi bagi pegawai serta membimbing pegawai dalam pelaksanaan tugas sehari-hari akan membantu pegawai dalam peningkatan kinerja pegawai tersebut.

\section{Pengaruh Organizational Citizen Behavior terhadap Kinerja Anggota BPKB Ditlantas Polda Jateng}

Berdasarkan hasil penelitian diketahui bahwa organizational citizen behavior berpengaruh positif terhadap kinerja anggota BPKB Ditlantas Polda Jateng yang ditunjukkan dengan taraf signifikansinya $0,039(<0,05)$. Artinya, jika organizational citizen behavior semakin baik, maka kinerja anggota BPKB Ditlantas Polda Jateng semakin meningkat. Hal tersebut berarti bahwa terbentuknya organizational citizen behavior dalam diri anggota BPKB Ditlantas Polda Jateng, dapat menjadikan anggota merasa memiliki kewajiban untuk memajukan organisasi. Hal tersebut dilakukan dengan semakin menunjukkan kinerja yang lebih baik. 
Penelitian terdahulu yang dilakukan oleh Chelagat, dkk (2015) menunjukkan bahwa organizational citizen behavior merupakan faktor penting dalam kinerja karyawan. Penelitian lain yang dilakukan oleh Ratnasari (2010) menunjukkan bahwa organizational citizen behavior terdiri dari kepatuhan, partisipasi, dan loyalitas memiliki pengaruh terhadap kinerja personil Poltabes Barelang. Faktor yang paling dominan berpengaruh terhadap kinerja personil Poltabes Barelang adalah partisipasi. Putri dan Utami (2017) juga menyimpulkan hasil penelitiannya bahwa secara simultan (bersama-sama) pada setiap variabel bebas yang merupakan dimensi organizational citizen behavior menunjukan variabel Altruism (X1), Conscientiousnes (X2), Sportsmanship (X3), Courtesy (X4), Civic virtue (X5) mempunyai pengaruh yang signifikan secara simultan terhadap kinerja karyawan.

\section{PENUTUP}

\section{Simpulan} berikut:

Berdasarkan hasil penelitian maka dapat diambil beberapa simpulan sebagai

1. Terdapat pengaruh positif remunerasi terhadap organizational citizen behavior. Hal ini berarti bahwa semakin tinggi remunerasi, maka akan semakin tinggi pula organizational citizen behavior.

2. Terdapat pengaruh positif kepuasan kerja terhadap organizational citizen behavior. Hal ini berarti bahwa semakin tinggi kepuasan kerja, maka akan semakin tinggi pula organizational citizen behavior.

3. Terdapat pengaruh positif kepemimpinan transformasional terhadap organizational citizen behavior. Hal ini berarti bahwa semakin baik kepemimpinan transformasional, maka akan semakin tinggi pula organizational citizen behavior.

4. Terdapat pengaruh positif remunerasi terhadap kinerja anggota BPKB Polda Jateng. Hal ini berarti bahwa semakin tinggi remunerasi, maka akan semakin tinggi pula kinerja anggota BPKB Polda Jateng.

5. Terdapat pengaruh positif kepuasan kerja terhadap kinerja anggota BPKB Polda Jateng. Hal ini berarti bahwa semakin tinggi kepuasan kerja, maka akan semakin tinggi pula kinerja anggota BPKB Polda Jateng.

6. Terdapat pengaruh positif kepemimpinan transformasional terhadap kinerja anggota BPKB Polda Jateng. Hal ini berarti bahwa semakin baik kepemimpinan transformasional, maka akan semakin tinggi pula kinerja anggota BPKB Polda Jateng.

7. Terdapat pengaruh positif organizational citizen behavior terhadap kinerja anggota BPKB Polda Jateng. Hal ini berarti bahwa semakin tinggi organizational citizen behavior, maka akan semakin tinggi pula kinerja anggota BPKB Polda Jateng.

\section{Implikasi Manajerial}

Saran yang dapat diberikan dengan mengacu pada hasil penelitian ini adalah sebagai berikut:

1. Pada variabel remunerasi, khususnya indikator remunerasi yang diberikan adil, Polri disarankan mempertimbangkan besarnya remunerasi berdasarkan tanggung jawab yang diterima anggota Polri, sehingga semakin dapat meningkatkan kinerja anggota Polri. Hal ini dikarenakan masih terdapat anggota dengan jenjang kepangkatan yang sama, namun memiliki tanggung jawab yang lebih berat dan mendapatkan remunerasi dalam jumlah yang sama. Polri disarankan agar memberikan bonus 
tersendiri di luar remunerasi bagi anggota yang memiliki tanggung jawab lebih berat tersebut.

2. Pada variabel kepuasan kerja, khususnya pada indikator sifat pekerjaan, Ditlantas Polda Jateng disarankan dapat meningkatkan kemampuan yang dimiliki anggota bagian BPKB dengan jalan mengikutsertakan anggota dalam pelatihan ataupun kejuruan yang sesuai dengan tanggungjawab pekerjaan, sehingga dapat menunjang penyelesaian setiap tugas di bagian BPKB.

3. Pada variabel kepemimpinan transformasional, khususnya pada indikator atributed charisma, pimpinan pada bagian BPKB Ditlantas Polda Jateng dapat lebih memberikan kepercayaan kepada anggota untuk melaksanakan pekerjaannya.

4. Pada variabel organizational citizen behavior, khususnya pada indikator civic virtue, anggota bagian BPKB Ditlantas Polda Jateng disarankan turut aktif mengikuti setiap bentuk pelatihan yang ada di organisasi, sehingga semakin terlibat dan menjadi bagian yang tidak terpisahkan pada Kepolisian.

5. Pada variabel kinerja, khususnya pada indikator kemampuan teknis, Ditlantas Polda Jateng disarankan dapat meningkatkan sarana dan prasarana yang menunjang pelaksanaan pekerjaan, sehingga anggota bagian BPKB Ditlantas Polda Jateng dapat semakin menunjukkan kinerja yang maksimal.

\section{Keterbatasan dalam Penelitian}

Model yang dibangun dari variabel yang digunakan dalam penelitian ini belum sempurna, karena kemampuan menjelaskan dari keseluruhan variabel dalam model, tidak mencapai Adjusted RSquare sebesar 1 atau 100\%, seperti remunerasi, kepuasan kerja, kepemimpinan transformasional, dan organizational citizen behavior menjelaskan sebesar 62,9\% kinerja anggota BPKB Ditlantas Polda Jateng. Artinya, masih terdapat variabel lain yang perlu dimasukkan selain remunerasi, kepuasan kerja, kepemimpinan transformasional, dan organizational citizen behavior, karena kemampuan menjelaskan variabel-variabel ini masih jauh dari sempurna.

\section{DAFTAR PUSTAKA}

Agustiningsih, H. N., Thoyib, A., dan Noermijati, D. H. 2016. The Effect of Remuneration, Job Satisfaction and OCB on the Employee Performance. Science Journal of Business and Management. Vol. 4. No.6: 212-222.

Arifiani, R. S., Astuti, E. S., dan Ruhana, I. 2016. Pengaruh Kepemimpinan Transformasional terhadap Organizational Citizenship Behavior dan Kepuasan Kerja (Studi pada Tenaga Perawat RSUD. Dr. Saiful Anwar Malang). Jurnal Administrasi Bisnis (JAB). Vol. 33 No. 1: 127-135.

Aziz, A., dan Niswah, F. 2016. Pengaruh Remunerasi terhadap Kinerja Pegawai Kantor Pelayanan Pajak Pratama Tuban. AGORA. Vol. 4, No. 1: 1-11.

Bana, A. 2015. Pengaruh Kepemimpinan Transformasional dan Lingkungan Kerja Fisik terhadap Kinerja Pegawai dengan Motivasi Kerja Sebagai Variabel Pemediasi (Studi Pada Perusahaan Daerah Air Minum (PDAM), Kota Kendari). Jurnal Bisnis dan Manajemen. Vol. 3 No.1: 1-16.

Chelagat, L. J., Kiprop, C. P., dan Kemboi, A. 2015. Effect of Organizational Citizenship Behavior on Employee Performance in Banking Sector, Nairobi 
County, Kenya. International Journal of Business, Humanities and Technology. Vol. 5, No. 4: 55-61.

Fitrianasari, D., Nimran, U., dan Utami, H. N. 2013. Pengaruh Kompensasi dan Kepuasan Kerja terhadap Organizational Citizenship Behavior (OCB) dan Kinerja Karyawan (Studi pada Perawat Rumah Sakit Umum "Darmayu" di Kabupaten Ponorogo"). Jurnal Profit Vol. 7 No.1: 12-24.

Gunawan, R. 2016. Pengaruh Kepemimpinan Transformasional terhadap Organizational Citizenship Behavior (OCB) pada PT First Marchinery Tradeco Cabang Surabaya. AGORA. Vol. 4, No. 1: 60-66.

Gustika, R. 2013. Pengaruh Pemberian Remunerasi terhadap Kinerja Anggota Polri Polres Pasaman (Studi Kasus Anggota Polri yang Berpangkat BRIPDA S/D BRIPKA). e-Jurnal Apresiasi Ekonomi. Vol. 1. No. 1: 22-31.

Hendarto, D. 2013 Pengaruh Kepuasan Kerja terhadap Organizational Citizenship Behavior Pegawai Negeri Sipil Dinas Perikanan dan Peternakan Pemerintah Kota Samarinda. Fakultas Psikologi Universitas 17 Agustus 1925 Samarinda.

Muhdiyanto. 2016. Pengaruh Kepemimpinan Transformasional terhadap Kinerja yang di Moderasi Kecerdasan Emosional (Studi Empiris di Kantor DPRD Kota dan Kabupaten Magelang. http://www.novapdf.com.

Munandar, Ashar, Sunyoto. 2012. Psikologi Industri dan Organisasi. Jakarta: Penerbit Universitas Indonesia.

Ningsih, F. R., dan Arsanti, T. A. 2014. Pengaruh Job Satisfaction terhadap OCB dan Turnover Intention. Benefit Jurnal Manajemen dan Bisnis. Volume 18, Nomor 1: $41-48$.

Nurizki, Y. R 2015. Pengaruh Kepuasan Kerja terhadap Kinerja Polisi Lalu Lintas di Polresta Bogor. Bogor: Universitas Gunadarma.

Podsakoff, P. M., MacKenzie, S. B., Paine, J. B., \& Bachrach, D. G. 2000. Organizational Citizenship Behaviors: A Critical Review Of The Theoretical And Empirical Literature And Suggestions For Future Research. Journal of Management. Vol. 26, No. 3.

Putri, Y. D., dan Utami, H. N. 2017. Pengaruh Organizational Citizenship Behavior (OCB) terhadap Kinerja (Studi pada tenaga Perawat Ruang Rawat Inap Rumah Sakit Baptis Batu). Jurnal Administrasi Bisnis (JAB). Vol. 46 No.1: 27-34.

Rohayati, A. 2014. Pengaruh Kepuasan Kerja terhadap Organizational Citizenship Behavior : Studi Pada Yayasan Masyarakat Madani Indonesia. SMART - Study \& Management Research | Vol XI, No. 1: 20-38. 
Sitepu, R. 2015. Pengaruh Disiplin Kerja dan Kinerja Karyawan dalam Meningkatkan Produktifitas Kerja pada CV. Immanuel Furniture Surabaya. Media Mahardhika. Vol. 14 No. 1. Surabaya : STIE Mahardhika Surabaya.

Subhi, E. R. 2014. Pengaruh Kepemimpinan Transformasional terhadap Kinerja Karyawan dengan Penghargaan Sebagai Variabel Moderating. Jurnal Ilmu \& Riset Manajemen Vol. 3 No. 2. Sekolah Tinggi Ilmu Ekonomi Indonesia (STIESIA) Surabaya.

Supriyanto, A., dan Triyanto. 2014. Pengaruh Kepuasan Kerja, Kepemimpinan Transformasional dan Komitmen Organisasional pada Kinerja Karyawan, dengan Organizational Citizenship Behavior (OCB) sebagai Variabel Mediasi. Riset Manajemen \& Akuntansi. Volume 5 Nomor 10: 24-40.

Susanti dan Palupiningdyah. 2016. Pengaruh Kepuasan Kerja dan Komitmen Organisasi terhadap Kinerja Karyawan dengan Turnover Intention Sebagai Variabel Intervening. Management Analysis Journal. Vol. 5. No. 1: 77-86.

Sutrisno, Edi. 2009. Manajemen Sumber Daya Manusia. Jakarta: Prenada Media Group.

Tan, R., dan Tarigan, Z. J. H. 2017. Pengaruh Kompensasi dan Kepuasan Kerja terhadap Organizational Citizenship Behavior (OCB) melalui Motivasi Kerja sebagai variabel intervening pada 3H Motosport. AGORA. Vol. 5, No. 1: 1-8.

Torang, S. 2013. Organisasi dan Manajemen: Perilaku, Struktur, Budaya dan Perubahan Organisasi. Bandung: Alfabeta.

Undang-Undang Republik Indonesia Nomor 22 Tahun 2009 tentang Lalu Lintas dan Angkutan Jalan.

Walter, Keller, R ,T. 1998. Transformasional Leadership and The Performance of Research and Development Project Group. Journal of Management. Vo; 18. No. 3, 489-501.

Wilfred, O. N., Elijah, C. M., dan Muturi, W. 2014. Effect of Remuneration on Employees Performance in the Ministry of Internal Security: A Case of Kisii County. International Journal of Human Resource Studies. Vol. 4, No. 1: 223231.

Zulbadi., Anisah, H. U., dan Dahniar. 2016. Pengaruh Kepemimpinan Transformasional dan Komitmen Organisasi terhadap organizational Citizenship behavior (OCB) terhadap Karyawan PDAM Bandarmasih Kota Banjarmasin. Jurnal Wawasan Manajemen. Vol. 2, Nomor 1: 31-42. 